\title{
TINGKAT KESUKAN JENIS MAKANAN DAN PENGARUHNYA TERHADAP PERTAMBAHAN BERAT BADAN TIKUS EKOR PUTIH (Rattus xanthurus) DI PENANGKARAN $E X$-SITU
}

\author{
Seysi R.F. Walukow, H.J. Kiroh*, I. Wahyuni, R.S.H. Wungow \\ Fakultas Peternakan Universitas Sam Ratulangi Manado, 95115
}

\begin{abstract}
ABSTRAK
Tikus ekor putih (Rattus xanthurus) adalah salah satu jenis tikus endemik Sulawesi Utara yang berstatus terancam punah (near threatened). Metode yang digunakan dalam penelitian ini ialah metode observasi. Penelitian ini dilakukan untuk memberikan informasi tentang jenis makanan yang paling disukai dan pengaruhnya terhadap pertambahan berat badan, konsumsi makanan dan efisiensi penggunaan makanan tikus ekor putih (Rattus xanthurus) sehingga dapat dimanfaatkan dalam upaya budidaya. Hasil penelitian menunjukan bahwa jenis makanan yang paling disukai tikus ekor putih (Rattus xanthurus) betina adalah buah pepaya 55,62 gr/ekor/hari sedangkan jantan lebih menyukai buah pisang 49,28 gr/ekor/hari. Pertambahan berat badan pada jantan lebih tinggi 17,79 gr/ekor/hari dibandingkan betina lebih rendah 10,09 gr/ekor/hari dengan pemberian makanan 60 gr/ekor/hari. Efisiensi penggunaan makanan tertinggi terdapat pada jantan, kondisi tersebut dapat diartikan bahwa jumlah konsumsi cukup memberikan kontribusi untuk pertambahan berat badan tikus ekor putih (Rattus xanthurus). Dari hasil penelitian ini dapat disimpulkan bahwa tikus ekor putih (Rattus xanthurus) lebih menyukai buah papaya dibandingkan dengan makanan segar lainnya.
\end{abstract}

*Kosepondensi (corresponding author)

Email: hengkijohanis.26@gmail.com
Kata Kunci: Tingkat Kesukaan, Pertambahan Berat Badan, Tikus Ekor Putih

\begin{abstract}
THE PREFERENCE OF FOOD TYPE AND THE INFLUENCE ON WEIGHT GAIN OF WHITE TAILED RAT (Rattus xanthurus) IN EX-SITU BREEDING. White tailed rats (Rattus xanthurus) is one of the endemic species of North Sulawesi that has the status of near threatened. The method used in this study is the method of observation. This research was conducted to provide information about the most preferred type of food and its effect on body weight gain, food consumption and the efficient use of white rat (Rattus xanthurus) so that they can be utilized in animal breeding business. The results showed that the type of food most preferred by the White Tailed Rat (Rattus xanthurus) female was papaya fruit $55.62 \mathrm{gr} / \mathrm{head} /$ day while males preferred the banana $49.28 \mathrm{gr} /$ head / day. Weight gain in males is higher $17.79 \mathrm{~g} /$ head / day compared to females $10.09 \mathrm{~g} /$ head / day lower with $60 \mathrm{gr} /$ head / day feeding. The highest efficiency of food use is found in males, this condition can be interpreted that the amount of consumption is enough to contribute to the weight gain of white tailed rats (Rattus xanthurus). The results of this study it can be concluded that the white tailed rat (Rattus xanthurus) prefers papaya fruit compared to other fresh foods.
\end{abstract}

Keywords: Preference, Weight gain, Whitetailed rat 


\section{PENDAHULUAN}

Indonesia memiliki hutan tropik yang kaya dengan berbagai flora dan fauna yang menjadi sumber pemenuhan berbagai kebutuhan manusia. Flora dan fauna yang menjadi potensi Indonesia kurang mendapatkan perhatian serius dari berbagai pihak untuk dikembangkan. Salah satu kawasan di Indonesia yang dengan biodiversitas yang tinggi adalah pulau Sulawesi, yang merupakan pulau yang sangat unik karena terletak di kawasan garis wallacea. Biodiversitas satwa di Sulawesi memiliki endemisitas yang sangat tinggi di dunia. Keunikan fauna vertebratanya telah menempatkan Sulawesi sebagai lokasi keanekaragaman hayati global (Whitten et al. 1987).

Salah satu satwa endemik yang ada di Sulawesi adalah tikus ekor putih (Rattus xanthurus) yang habitat aslinya terdapat di daerah timur laut Sulawesi. Tikus ekor putih juga menyukai jenis makanan dari tanaman budidaya seperti kangkung, daun pepaya, pucuk singkong, daun umbi rambat, kubis, wortel, pucuk ubi rambat, kubis, wortel. Di daerah Minahasa, tikus dikenal dengan nama lokal "turean" (Wahyuni, 2005) dan telah dijadikan sebagai makanan pada berbagai pesta adat ataupun makanan sehari-hari.
Menagkarkan satwa liar berarti memindahkan satwa liar dari pola hidup di alam bebas ke dalam pola hidup yang terkurung dan diatur oleh manusia (Alikodra, 2010). Menurut Wahyuni (2005) meningkatnya permintaan terhadap daging tikus ekor putih, memiliki dampak positif terkait peluang dan prospek pengembangannya sebagai satwa harapan, namun di sisi lain juga dapat berdampak negatif karena masih mengandalkan perburuan di habitat asli dan telah mengancam populasinya (Kennerley dan Clayton, 2016). Prospek kedepan tikus ekor putih berpeluang sangat baik dilihat dari sosial budaya, ekonomi goegrafis dan alamnya. Hal ini sesuai dengan data terakhir yang menunjukan bahwa kecenderungan populasi tikus ekor putih menurun (IUCN, 2008), sehingga perlu dilakukan usaha perlindungan dan pemanfaatan secara lestari. Daging tikus ekor putih dapat diterima sebagai alternatif hewan penghasil daging yang berpotensi untuk budidaya.

Berdasarkan informasi-informasi terdahulu tentang kehidupan dari tikus ekor putih (Rattus xanthurus) yang populasinya semakin menurun serta belum adanya informasi-informasi ilmiah yang berkaitan dengan jenis-jenis makanan dan tingkat kesukaannya, maka telah dilakukan penelitian secara ilmiah untuk mengetahui 
tingkat kesukaan tikus ekor putih ini dalam meresponi beberapa jenis makanan yang disukainya sehingga penangkaran dan budidaya dapat dilaksanakan secara ilmiah dalam rangka menyiapkan jenis-jenis makanan kuliner khas Minahasa untuk menunjang program ekowisata di Sulawesi Utara.

\section{MATERI DAN METODE PENELITIAN}

Penelitian ini dilaksanakan pada tanggal 23 Agustus s/d 21 September 2019 di Desa Pineleng, Kabupaten Minahasa Provinsi Sulawesi Utara. Materi yang digunakan dalam penelitian ini adalah tikus ekor putih (Rattus xanthurus) sebanyak 6 ekor yang terdiri dari 4 ekor jantan dan 2 ekor betina yang dipelihara di kandang penangkaran dengan umur tikus rata-rata 8 bulan. Materi lain yang digunakan adalah Pakan tikus ekor putih (Rattus xanthurus) yang diberikan secara kafetaria seperti: pepaya, pisang, kangkung, sawi putih, kol, kentang, wortel, kelapa, nenas, dan umbi jalar. Air minum diberikan secara ad libitum (diberikan secara tak terbatas). Penelitian ini menggunakan beberapa peralatan sehingga mempermudah penelitian yang akan dilakukan baik dalam pengamatan maupun dalam pengambilan data seperti: alat tulis menulis, kamera, jam tangan, timbangan digital, timbangan gantung. Penelitian ini menggunakan tiga buah kandang berbentuk persegi panjang dengan ukuran kandang 18 $\mathrm{cm} \times 25 \mathrm{~cm}$ x $50 \mathrm{~cm}$ yang disekat masingmasing kandang menjadi dua bagian.

Tikus terlebih dahulu ditimbang dengan timbangan gantung untuk diambil berat awal sebelum penelitian. Sebelum makanan diberikan pada tikus semua bahan makanan ditimbang terlebih dahulu, kemudian sisa makanan pagi ditimbang kembali pada sore hari sebelum pemberian makanan untuk malam hari, sisa makanan yang diberikan pada malam hari ditimbang pada besok hari (pagi) sebelum diberikan makanan yang baru. Penelitian tingkat kesukaan dari jenis-jenis makanan yang diberikan selama 6 hari dengan pemberian 10 jenis makanan. Makanan disajikan secara kafetaria (bebas pilih) untuk menentukan persentase makanan yang paling disukai. Waktu pengambilan data yaitu pagi 06:00 dan malam 19:00.

Variabel yang diukur dalam penelitian ini adalah: Tingkat kesukaan jenis-jenis makanan. Untuk mengetahui tingkat kesukaan makanan dilihat dari berapa banyak yang dikonsumsi dan disukai. Variabel lainnya adalah pertambahan berat badan diperoleh dengan cara penimbangan setiap minggu. Pertambahan berat badan 
diukur dari berat badan akhir (g/ekor/h) dikurangi berat badan awal (g/ekor/h). Konsumsi makanan diukur dari jumlah makanan yang diberikan (g/ekor/h) dikurangi jumlah makanan sisa (g/ekor/h) dibagi jumlah satwa. Efisiensi penggunaan makanan adalah nilai pertambahan berat badan harian dibagi konsumsi makanan perhari.

Data yang diperoleh selama penelitian dianalisis secara deskriptif dan disajikan dalam bentuk Tabel, Grafik, dan Diagram.

\section{HASIL DAN PEMBAHASAN}

\section{Tingkat Kesukaan}

Tingkat kesukaan makanan tikus dipengaruhi oleh bentuk, tekstur, bau dan warna makanan. Jantan lebih menyukai papaya dibandingkan dengan pisang dan sayuran disebabkan oleh papaya memiliki warna dan aroma yang disukai tikus ekor putih dibandingkan bahan makanan yang lain. Hasil pengamatan selama 6 hari dengan pemberian 10 jenis makanan menunjukkan bahwa hanya 4 jenis makanan yang paling disukai seperti pada Gambar 1. Jenis makanan seperti ini yang dijadikan dasar untuk digunakan pada penelitian selanjutnya. Dari hasil pengamatan pada Gambar 1 menunjukan bahwa buah-buahan dan sayuran lebih disukai tikus ekor putih (Rattus xanthurus) dimana betina lebih banyak mengkonsumsi pepaya, hal ini disebabkan kandungan air yang terdapat pada buah pepaya lebih banyak (Ramli dan Hamzah, 2007). Penelitian Wahyuni (2005) menyatakan bahwa buah-buahan dan sayuran lebih disukai dibandingkan umbiumbian, bila disajikan bersamaan buahbuahan lebih dahulu dimakan, kemudian daun sayuran dan umbi-umbian. Ketersediaan komponen pada buah-buahan sangat dimanfaatkan secara langsung sebagai sumber energi oleh tikus ekor putih. Tingkat kesukaan satwa terhadap suatu bahan makanan segar sangat bervariasi. Ketertarikan satwa ini terhadap jenis-jenis makanan baru merupakan suatu bukti bahwa adanya peluang untuk membudidayakan satwa-satwa tersebut dalam penangkaran. Kemampuan hewan beradaptasi dengan lingkungan baru antara lain dapat dilihat dari kerangaman makanan yang disukai dan dikonsumsi. Pada penelitian ini daya adaptasi tikus ekor putih terhadap makanan cukup tinggi. Hal ini dilihat berdasarkan jenis makanan yang disukai. Preferensi makanan merupakan kebebasan tikus dalam memilih berbagai jenis makanan yang disediakan untuk mengetahui jenis mana yang paling disukai maupun tidak disukai (Rahayu et al., 2014) 


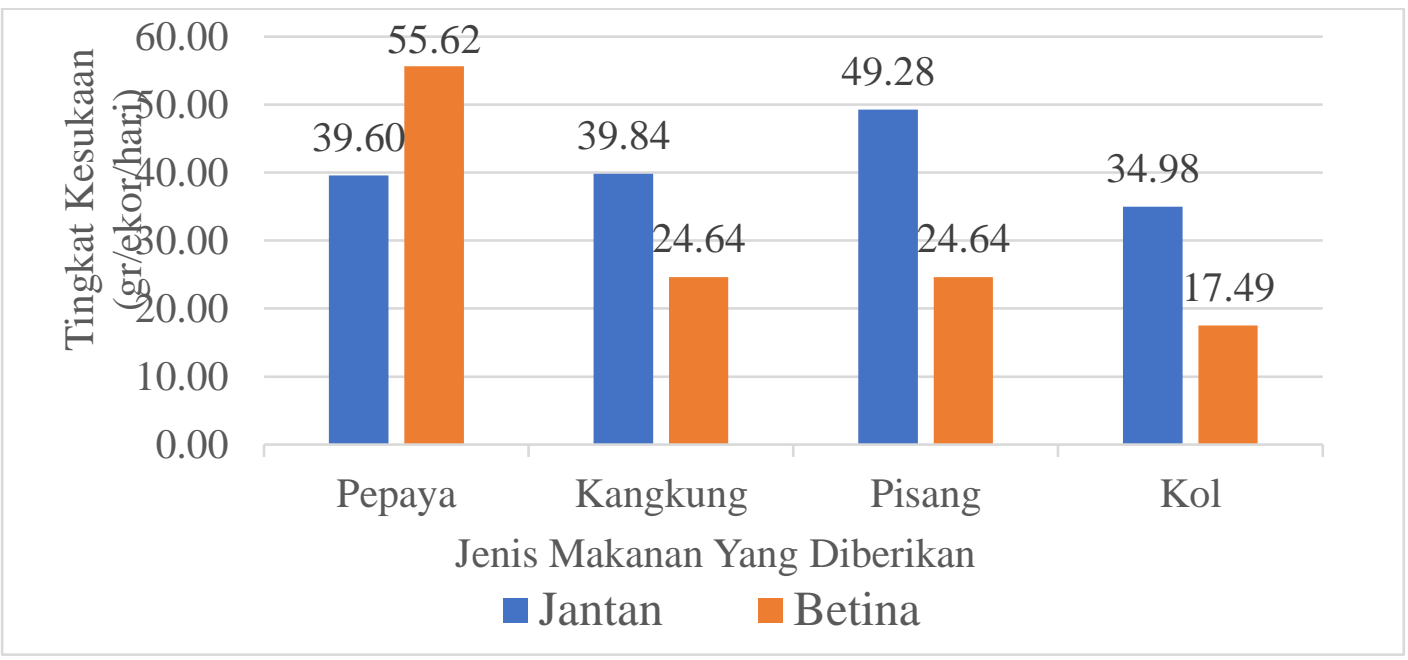

\section{Gambar 1. Tingkat kesukaan jenis-jenis makanan yang disukai tikus ekor putih (Rattus xanthurus) jantan dan betina}

\section{Konsumsi Makanan}

Hasil penelitian ini menunjukan bahwa konsumsi makanan tikus ekor putih betina lebih tinggi dibandingkan jantan. Hasil tersebut menunjukan bahwa tikus ekor putih betina mengkonsumsi buah pepaya lebih dari $50 \%$ dari makanan lainnya (gambar 2). Makanan yang berasal dari tumbuhan dimanfaatkan sebagai sumber energi (Fatmal, 2008). Hasil penelitian ini menunjukan bahwa Rattus xanthurus memiliki kesamaan dengan tikus ekor putih (Maxomys hellwandi) yang lebih menyukai pepaya di antara makanan segar lainnya (Upa et al., 2007; Wahyuni, 2005). Diduga pepaya memiliki tekstur dan warna lebih menarik juga memiliki aroma dan bau yang lebih disukai. Konsumsi makanan dipengaruhi oleh tingkat kesukaan terhadap makanan. Gambar 2 memperlihatkan pola tingkat kesukaan jenis makanan selama penelitian. Tikus ekor putih (Rattus xanthurus) membutuhkan makakan setiap hari kira-kira $10 \%$ dari bobot tubuhnya, tergantung dari kandungan air dan gizi dalam makanannya (Patrick dan Schaible, 1980).

\section{Pertambahan Berat Badan}

Hasil penelitian ini menunjukan bahwa dari jenis makanan yang diberikan seperti pada gambar 3 ternyata dapat meningkatkan berat badan tikus ekor putih dengan rata-rata jantan 17,79 gram/ekor/hari dan betina 10,09 gram/ekor/hari selama 21 


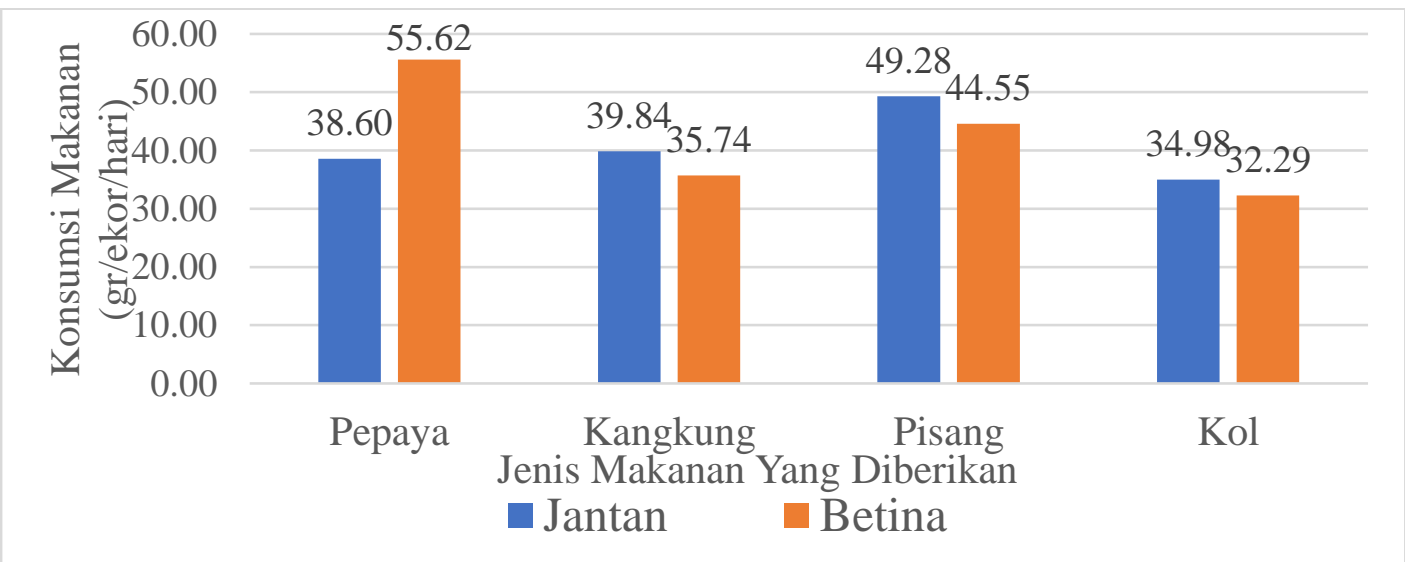

\section{Gambar 2. Konsumsi makanan}

hari pengamatan walaupun konsumsi jantan lebih tinggi dibandingkan dengan makanan tertinggi pada betina. Hal ini diduga bahwa walaupun konsumsi makanan tertinggi pada betina. Hal ini diduga bahwa pertumbuhan tikus jantan lebih cepat dibandingkan tikus betina, dikarenakan jantan lebih banyak mengkonsumsi buah pisang karena teksturnya lebih padat dan memiliki protein yang tinggi berbeda dengan betina yang cenderung lebih banyak mengkonsumsi buah pepaya (Gambar 3). Hasil ini tidak berbeda dengan Pertambahan bobot badan tikus putih (Rattus norvegicus) dimana jantan lebih tinggi dibanding betina (Sayuti dan Parakkasi, 2009). Pada Gambar 3 memperlihatkan bahwa pertambahan berat badan tikus ekor putih (Rattus xanthurus) betina. Walaupun jumlah konsumsi betina lebih tinggi dibandingkan jantan. Pertumbuhan tikus jantan lebih cepat tetapi lebih cepat mencapai pertumbuhan optimal. Sedangkan pertumbuhan tikus ekor putih betina lebih lambat tetapi lebih lambat juga mencapai pertumbuhan optimal. Menurut Smith dan Mangkoewidjojo (1988) bahwa pertumbuhan tikus jantan lebih cepat dibandingkan dengan betina dan bobot jantan tua dapat mencapai 500 gram tetapi tikus betina jarang lebih dari 350 gram. Terjadinya perbedaan tersebut mungkin disebabkan oleh hormon kelamin (Testosteron). 


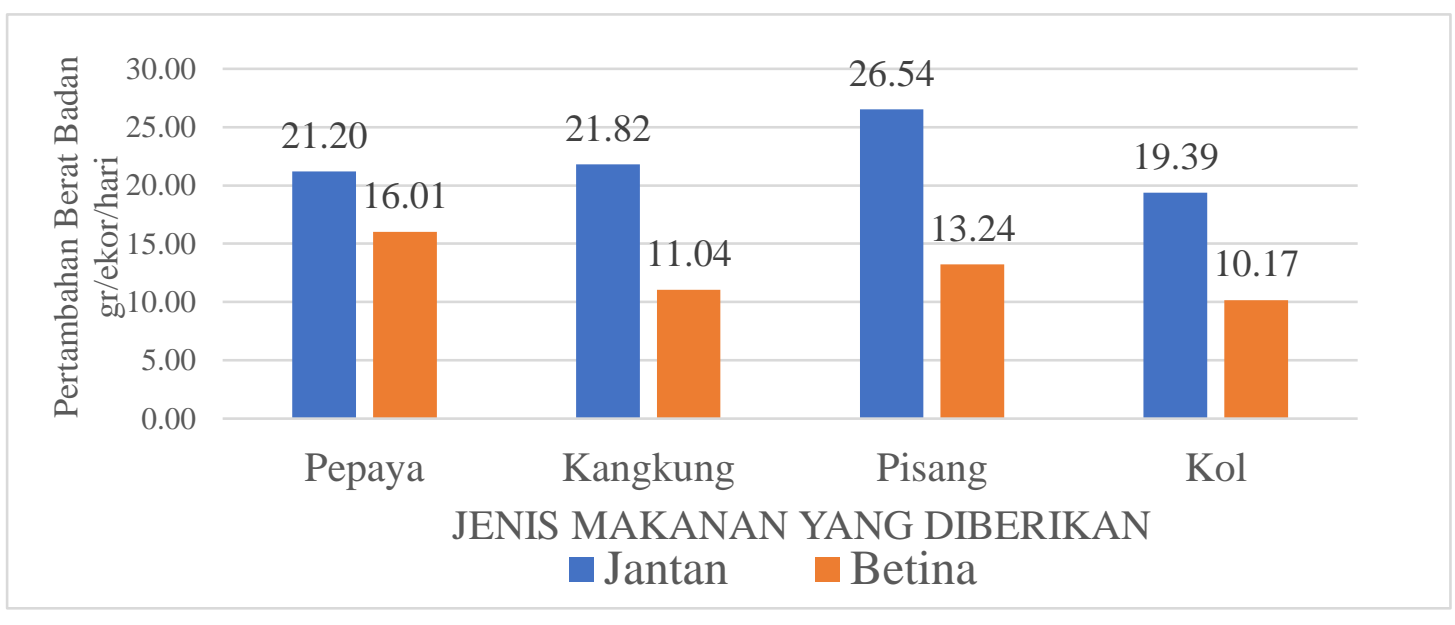

Gambar 3. Pertambahan berat badan

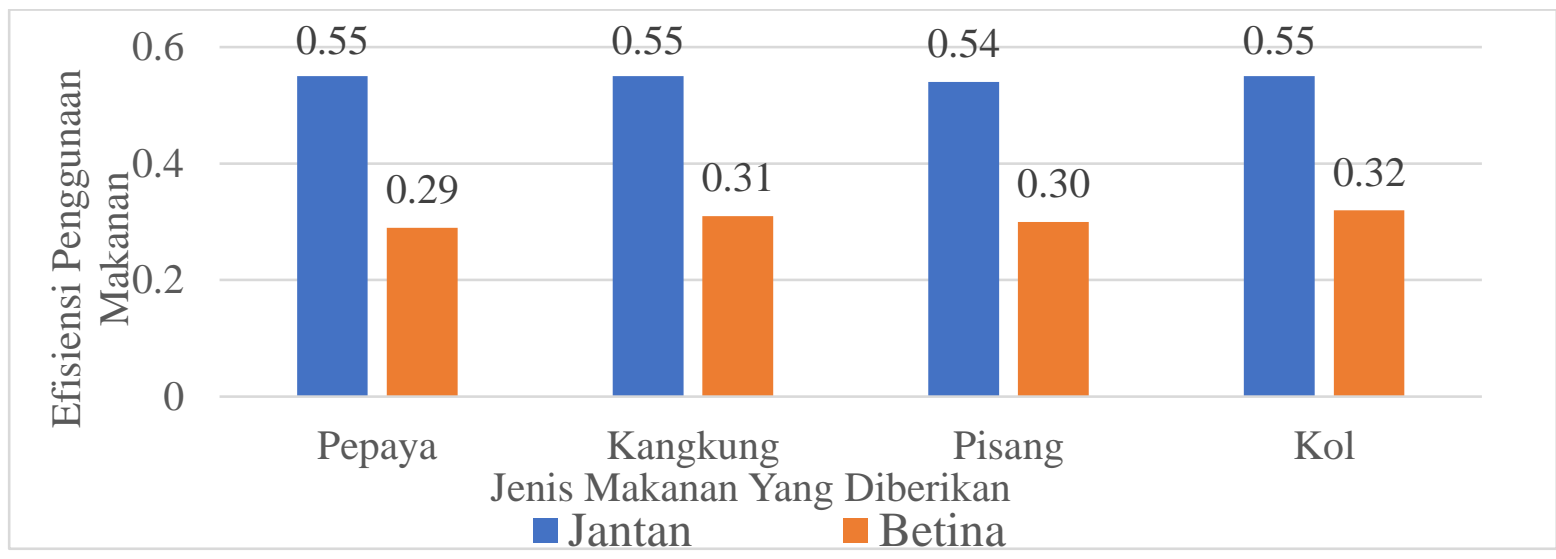

Gambar 4. Efisiensi Penggunaan Makanan

\section{Efisiensi Penggunaan Pakan}

Hasil pengamatan pada gambar 4 menunjukan bahwa Jantan mempunyai efisiensi makanan yang tertinggi dibandingkan betina. Hasil penelitian menunjukan bahwa semakin kecil efisiensi penggunaan makanan antara jantan dan betina memberi gambaran bahwa penggunanan makanan semakin baik karena tergambar dari pertambahan berat badan tikus ekor putih yang diteliti (Gambar 4).

Tingkat kesukaan terhadap makanan juga merupakan faktor penting yang menentukan efisiensi penggunaan makanan, 
sehingga perlu diperhatikan untuk mendapatkan produksi yang tinggi. Keefisienan pakan dapat dilihat dari nilai konversi makanan, semakin rendah angka konversi maka efisiensi penggunaan makanan semakin tinggi. Hasil penelitian menunjukan bahwa efisiensi makanan dimaksudkan untuk memberikan gambaran konsumsi dan pertambahan berat badan (Aminah dan Yusuf, 2015).

\section{KESIMPULAN}

Berdasarkan hasil penelitian ini dapat disimpulkan bahwa tikus ekor putih (Rattus xanthurus) betina lebih menyukai buah pepaya sedangkan jantan lebih menyukai buah pisang dibandingkan dengan makanan lainnya. Peningkatan berat badan pada jantan lebih tinggi dibandingkan betina. Efisiensi penggunaan makanan pada jantan sangat tinggi dibandingkan betina.

\section{DAFTAR PUSTAKA}

Alikodra, H.S. 2010. Teknik pengelolaan satwa liar. Cetakan Kedua. IPB Press. Bogor.

Aminah, S dan M. Yusuf. 2015. Efisiensi Pakan, Berat Badan Dan Panjang Tulang Tikus Yang Mengkonsumsi Kejale Selama 6 Minggu. Prosiding Seminar Nasional \& Internasional Universitas Muhammadiyah Semarang. Pp. 451-459
Fatmal, I. 2008. Preferensi Tikus (Rattus norvegicus) terhadap jenis umpan pada tanaman padi sawah. Jurnal Florantek 3:73-86.

IUCN, $2008 . \quad$ Redlist. https://www.iucnredlist.org/species/ 19372/115150466 [diakses 27 April 2019].

Kennerley, R dan E. Clayton. 2016. Rattus xanthurus (errata version published in 2017). The IUCN Red List of Threatened Species 2016 : e.T19372A115150466. http//dx.doi.org/10.2305/IUCN.UK. 2016-

3.RLTS.T19372A22444970.en. Downloaded on 06 May 2019.

Patrick, H. dan P.J. Schaible. 1980. Poultry Feeds and Nutrition. Avi Publishing C., Inc, Westport Connecticut.

Rahayu, M., P. Terry, S. Titi. 2014. Preferensi dan kemampuan makan tikus rumah (Rattus-rattus diardii) pada beberapa varietas beras (Oryza sativa L) di penyimpanan. Jurnal Agroteknos 4(1):66-70.

Ramli, R. dan F. Hamzah. 2017. Pemanfaatan buah pepaya (Carica papaya l.) dan tomat (Lycopersicum esculentum) dalam pembuatan Fruit Leather. JOM Bidang pertanian 4(1):1-9.

Sayuti, M dan A. Parakkasi. 2009. Performa pertumbuhan tikus putih (Rattus norvegicus) yang diberi ransum berbagai taraf limbah udang. Jurnal Agripet 9(2): 21-27.

Smith, J.B dan S. Mangkoewidjojo. 1988. Pemeliharaan, Pembiakan Dan Penggunaan Hewan Percobaan Di Daerah Tropis. UI Press Jakarta 
Upa, F. Saroyo dan D. Katili, 2007. Komposisi pakan tikus ekor putih (Maxomys hellwandii) di kandang. Jurnal Ilmiah Sains 17(1): 09-10.

Wahyuni, I. 2005. Tingkah Laku, Reproduksi, Dan Karakteristik Daging Tikus Ekor Putih (Maxomys hellwandi). Disertasi Institut Pertanian Bogor.

Whitten, A.J., M. Mustafa, G.S. Henderon. 1987. Ekologi Sulawesi. Gadjah Mada University Press.

Yogyakarta. 